\title{
ЛІНГВІСТИЧНІ СХЕМИ ІННЦАЦІЇ ЧИТАЧА В УКРАЇНОМОВНОМУ ДИСКУРСІ ЖАХІВ
}

\author{
ЯРОСЛАВА САЗОНОВА \\ Харківський національний педагогічний університет імені Г. С. Сковороди, \\ Харків - Україна \\ LINGWISTYCZNE SCHEMATY INICJACJI CZYTELNIKA \\ W UKRAIŃSKIM DYSKURSIE HORRORÓW \\ JAROSŁAWA SAZONOWA \\ Charkowski Narodowy Uniwersytet Pedagogiczny im. H. Skoworody, \\ Charków - Ukraina
}

STRESZCZENIE. Artykuł poświęcono problemowi tworzenia i percepcji tekstów hororrów w języku ukraińskim. Analiza tekstów horrorów ukraińskich pisarzy XIX wieku pozwoliła wyodrębnić i przedstawić schematy inicjacji czytelnika oraz wykazać specyfikę narodową tworzenia tekstów tego gatunku. Wnioski płynące z analizy pozwalają określić perspektywy dalszych badań w obrębie jednego języka,jak również w aspekcie porównawczym.

\section{LINGUISTIC SCHEMES OF READER'S INITIATION IN UKRAINIAN HORROR DISCOURSE}

\section{YAROSLAVA SAZONOVA}

H. S. Skovoroda Kharkiv National Pedagogical University, Kharkiv — Ukraine

ABSTRACT. The article is devoted to the problem of text creation and text perception of samples of horror genre in Ukrainian. The analysis of Ukrainian horror texts of the $19^{\text {th }}$ century allowed not only defining and formulating the reader's initiation schemes but also revealing national specificity of text creation in this genre. The results of the analysis presuppose further perspectives of these studies within the bounds of one language or comparatively.

$\mathrm{H}$

а початку XX ст. В. Пропп ${ }^{1}$ запропонував структурний підхід до класифікації казок, що грунтується на схемах взаємодії головного героя 3 іншими, які допомагають або заважають йому досягти основної мети, стаючи учасниками обряду посвячення, або ініціації, головного героя в новий статус переможця. Казковий обряд ініціації, на думку В. Проппа, — це відбиток соціального тотемічного ритуалу ініціації, але нез'ясованим залишається питання про історико-культурні й психологічні витоки цього обряду. У більш широкому сенсі на сучасному етапі розвитку гуманітарних наук явище ініціації тлумачиться як будь-який процес зміни соціального статусу або долучення до нових знань (наприклад, посвята в студенти).

Принциповим став той факт, що в процесі ініціації герой казки переходить iз реального світу (стале життя, рутинні обов'язки, закріплений соціальний статус) до казкового світу із чарівними істотами, фантастичними подіями, відсутністю межі між життям і смертю тощо. Цей процес можна порівняти із проце-

${ }^{1}$ В. Я. Про п п, Исторические корни волшебной сказки, Ленинград, 1986. 
сом сприйняття читачем текстів дискурсу жахів, адже адекватне розуміння таких текстів вимагає від нього спільної з автором історико-культурної пресупозиції, а головне - ідеологічного й психолого-емоційного підгрунтя для сприйняття й поділу авторської інтенції щодо вираження емоції страху.

Під ініціацією читача у вигаданому світі дискурсу жахів розуміємо первинне заглиблення в текст, у якому страшні об'єкти або події ще не вербалізовані, а використані лише окремі маркери-натяки на можливий розвиток сюжету. Іншими словами, стадія ініціації формує читацьке очікування в процесі сприйняття текстуㄹ․

Як зазначив А. Богатирьов ${ }^{3}$, такий сучасний напрям у лінгвістичних дослідженнях, як теорія текстотворення, повинен мати своїм предметом „схеми розгляду засобів текстової організації, в змістове навантаження яких входить указівка на тип інтенції цілого тексту". Відповідно, стадія ініціації може бути досліджена як частина цілої схеми тексту жахів. 3 огляду на теорію текстотворення й текстосприйняття ініціація читача в певний дискурс — це перший крок у процесі соціально поділеної комунікативної діяльності письменника й читача. Такий підхід відповідає актуальності досліджень у царині текстотворення, сформульованій А. Богатирьовим ${ }^{4}$ : „виявлення конструктивних принципів текстової організації у сфері естетичної комунікації”. Як зазначав Х. Ловкрафт американський письменник жанру жахів, "атмосфера — це найважливіша річ, адже остаточним критерієм достеменності є не гармонійна побудова сюжету, а створення відповідного відчуття".

Отже, мета статті - виявити вербальну репрезентацію первинних семіотичних знаків страху / тривоги як частини загальної смислоутворювальної схеми текстів жахів в українській літературній традиції.

Окремо зупинимося на з'ясуванні ідеологічної складової українських текстів дискурсу жахів. В. Шевчук у передмові до збірки Огненний змій указує на глибоке християнське коріння української літератури жахів, першими зразками якої вважаються Повість врем'яних літ і Патерик Печерський, де „святі змагалися 3 нечистою силою, що з'являлася до них ув образі жінок, чортів, страховищ, звірів, навіть ув образах святих чи й самого Ісуса Христа"6. Це дало поштовх до розвитку української літератури жахів у двох напрямах — дидактичноагітаційному та чудесному, фантастичному.

Іншою характерною рисою українських творів жахів уважається гумористичне ставлення до всього, що страхає. Як зауважує Ю. Винничук, „оригінальним українським внеском до скарбниці світової фантастичної літератури є саме казкова, або міфологічна фантастика, написана з гумором, дотепністю, а деколи відчутне тут і кепкування автора над самим читачем. <.. > У деяких творах те, що описувалося як абсолютно правдиве, наприкінці оповідання може піддаватися сумніву"7.

Описані вище специфічні риси українських літературних творів жахів неодмінно мають вплинути й на текстотворення дискурсу жахів загалом, і на лінгвістичні схеми ініціації читача зокрема.

${ }^{2}$ В. А. П и ща ль н и ко в а, Кониептуальный анализ поэтического текста, Барнаул, 1991.

${ }^{3}$ А. А. Богатыр е в, Индивидуация интениионального начала беллетристического текcma, Дис. докт. филол. наук, Тверь 2001, с. 5.

${ }^{4}$ Там же, с. 9.

${ }^{5}$ H. P. Lovecraft, Supernatural Horror in Literature, [в:] The Dark Descent, New York, 1987, c. 4.

${ }^{6}$ В. Ш е вч ук, У світі фантазій украйнського народу, [в:] Огненний змій. Фантастичні твори українських письменників 19 сторіччя, Київ 1990, с. 2.

${ }^{7}$ Ю. В и н н и ч у к, У зачарованім люстрі, [в:] Огненний змій..., с. 4. 
Матеріалом дослідження в межах статті стали літературні оповідання українських авторів ХІХ ст. Серед них чітко виокремлюється група оповідань, де ініціація читача відбувається відразу, безпосередньо на рівні назви оповідання, напр., Недобрий віщун Хоми Купрієнка ${ }^{8}$. Віщун — „той, хто віщує, пророкує що-небудь", його пророцтва можуть бути як добрими, так і злими, тож очікування читача відразу спрямовуються на несприятливий для головних героїв перебіг подій, про що вони були, очевидно, попереджені, але знехтували небезпекою. Уживання маркера віщун у назві ініціює також очікування уточнення, хто саме заподіє зло, адже віщун — це лише медіатор між реальним світом і потойбіччям. На початку оповідання автор вибудовує таку схему подальшого розгортання жахливого сюжету, що відповідає найдавнішому культурному страху перед реальним та потойбічним світами й незбагненним: диво - суб'єкт страху — зловмисна дія — опис жаху, що вербалізовано у відповідних маркерах (Хто не бував у селі К..., той і дива не бачив! — _..> у сьому селі стільки відьом, щзо мені здається, більш чим на всьому білому світі; а скільки пакостів вони роблять бідним людям, котрі тутечка живуть! — <..> дак у мене аж волосся дибом стало). Уживання лексем відьма, пакість у формі множини теж уважаємо комунікативно спрямованою тактикою, що дозволяє підсилити ефект впливу на читача.

За подібним принципом побудоване й оповідання Михайла Чайковського Могил ${ }^{10}$. Назва оповідання містить маркер могила, що спрямовує читацьке очікування сприйняття тексту, зацікавлюючи, хто ж там похований і що за події стали причиною смерті. У подальшому ініціація читача відбувається за поданою схемою: диво — оповідач-старий — суб'єкт страху — зловмисна дія — опис жаху: Коло Галчиния височіла Могила < ..> дивні речі про неї оповідали — <..> дід Левко, як у власній хаті, на ній гостював <.. > 一 з кущуів на Могилі виходили постаті, щзо мали дивні кшталти, скупчувалися, а потім, збивиись у вогненний стовп, звільна сунули до села - хто проїжджає біля ї̈ підніжжся, кров у жилах стигне, а волосся на голові диба стає - так страшно. Тут вербалізовано як диво, про яке переказують, суб'єкт страху, його зловмисні дії, так і фізіологічну реакцію людини на джерело страху. На позначення суб'єкта страху вжито семіотичний маркер - nocmamb. На нашу думку, використання саме такого семіотичного маркера підсилює напругу під час створення атмосфери жаху й впливає на очікування читача щодо подальшого страхітливого перебігу подій, адже суб'єкти й об'єкти страху, як і їхні дії, ще невідомі, тож неможливо передбачати будь-що, окрім здогадки про можливу страхітливу причину смерті похованих у могилі людей.

В іншому оповіданні Хоми Купрієнка Втоплениця ${ }^{11}$ читацьке очікування в процесі сприйняття тексту, а саме - процес ініціації в дискурс жахів відбувається теж на етапі знайомства 3 назвою. За українськими традиціями втоплениці (в міфології - русалки, мавки) мають легку вдачу, пустують, співають, танцюють, але можуть залоскотати до смерті, потягти під воду за собою або навіть відтяти голову. Головним для людини, яка натрапила на втопленицю, стає обережне поводження з нею, що вбереже від неприємностей або смерті. Створення атмосфери очікування й страху підсилено портретним описом утоплениці вже на стадії ініціації, хоча культурний досвід читача зазвичай достатній,

${ }^{8}$ Х. Купр і є н ко, Недобрий віщун, [в:] Огненний змій..., с. 75-86.

${ }^{9}$ Словник сучасної української мови, [в:] Електронний ресурс: http://sum.in.ua (11.04.2013).

${ }^{10}$ М. Ч ай ко в с ь к и й, Могила, [в:] Огненний змій..., с. 63-70.

${ }^{11}$ Х. Ку пр іє н ко, Втоплениия, [в:] Огненний змій.., с. 86-94. 
щоб уявити, як саме виглядає втоплениця. Тож етап ініціації побудовано так: оповідач-пастух - питання - опис страху - диво - причина страху: $A$ щзо, Миколо, чи все благополушно? - Ледве усі нічліжники не покидали своїх коней i не дали драла із лісу. - Панночка в білому платті, на голові гребінь, а намиста, намиста! - уся шия так золотом і сяє. Яка ж вона спереду має бути, думають хлопиі, коли ззаду така пишна. - Лице у панночки було синє, мов сукно, і руки сині, а із рота вода так $і$ крапала. На відміну від попередньо проаналізованих текстів, вербалізація дива в цьому оповіданні не несе негативної конотаціï, воно не лякає й не викликає відрази, аж поки не буде зазначено його викривлення або відхилення від норми. У нашому прикладі причина страху вербалізована описом ненормального кольору обличчя та рук і нетипової поведінки (вода з рота так $i$ крапала). Це дає підстави в процесі побудови текстотворчої схеми ініціації читача відокремити диво й причину страху. Наступні очікування читача стосуються роз'яснення, якої саме шкоди наробила втоплениця людям (побіжно зауважимо, хоча це й не становить дослідницького предмета, що очікування читача можуть не справджуватися. До такого засобу текстотворення вдаються інколи автори, щоб здивувати читача, що й відбулося в цьому оповіданні).

Чортова пригода Марка Вовчка ${ }^{12}$, хоча й належить до групи описуваних тут оповідей, що мають першим елементом етапу ініціації читача назву оповідання, відрізняється від вище проаналізованих саме національно забарвленим гумористичним ставленням до світу жахів, що вже відчувається в самій назві. Насамперед вона попереджає, що певні дії будуть відбуватися саме 3 чортом, а не за його сприяння 3 людиною, тим самим налаштовуючи читача на очікування радше пригодницького сюжету, а не переживання емоції страху. За іншою схемою будується й деталізація етапу ініціації: оповідач-п'яниця - твердження про диво - психологічна стійкість об'єкта - повторна клятва про правдивість слів - натяк на негаразди суб'єкта (Бачив на свої власні очі, оче як вас бачу. не ймете віри? Може, думаєте: поязичився Свирид Костомаха! - Приміром кажучи, якби вам той чорт пострічався, то у вас з переляку, мабуть, очкур би луснув, а я стрів, то мені й за ухом не засвербіло: чортяка, то нехай $і$ чортя$к а$, страшний, то нехай і страшний... Не в такому горщчику наварювали, та дякувати богу - ошамненько виїдали. Еге ж, бачив я його добре - не назирком, а так, як очю чарку, щзо передо мною. Якби приміг малювати, то намалював би вам і ріжки, $і$ копитиее. - Що б то мені його не розгледіти, попліч з ним сидючи та слухаючи, як він на своє лихо нарікає...). Саме наявність елемента схеми “психологічна стійкість об'єкта" значно знижує напругу й зменшує читацькі очікування щодо власне страху: чорт описаний як такий, що його справді бачили й не злякалися, а на думку психологів, уже відомий об'єкт не сприймається як страшний. Також на гумористичний настрій налаштовує згадка про нетверезий стан оповідача (бачив, як очю чарку, щзо передо мною), й читач, відповідно, надалі буде із сумнівом ставитися до правдивості його слів. До того ж, як стає відомо згодом, пригоди чорта пов'язані із загальнолюдською проблемою неподіленого кохання.

Подібна біда спіткала й чорта з оповідання Олекси Стороженка Закоханий чорт ${ }^{13}$. Цей твір, як видається, стоїть дещо осторонь і потребує більшої уваги, оскільки віддзеркалює не лише характерне для української культури й ментальності гумористичне ставлення до страхів, про що вже згадувалося, а й сповне-

\footnotetext{
${ }^{12}$ М. В о вч о к, Чортова пригода, [в:] Огненний змій..., с. 165-178.

${ }^{13} \mathrm{O}$. С т о р оже н ко, Закоханий чорт, [в:] Огненний змій..., с. 193-218.
} 
ний ліризму й співчуття навіть стосовно суб'єкта страху (чорта), коли він переживає емоційні страждання. Вживання семіотичного маркера чорт у назві, безперечно, вказує на інтенцію автора ввести читача до вигаданого світу жахів, але атрибутивна характеристика закоханий швидше не лякає, а зацікавлює читача, і його очікування від майбутнього сприйняття тексту мають інше психологічне підгрунтя. Це очікування в подальшому підкріплюється побудовою тексту в зовсім відмінний від інших текстів жаху спосіб: автор удається до пейзажних описів і милування українською землею та людьми, протиставляючи їх "Московщині": Здається, сама рідна нама Украӥна вийшла тобі назустріч: то спогляне на тебе гарячим сонцем, то притулиться пахучим холодком із темного лісу, то промовить піснею, то озветься соловейком, жайворонком, то неначе грається з тобою: затурчить у вухо горличею, залоскоче тихесенько вітерием. Так тобі весело, так легенько, мов у раю!.. Душа мліє, серие труситься, токотить, буцім що до тебе промовляє; не розбереш, що воно розказує, а слухаєи не наслухаєшся, як не наслухається мати своєї дитини, бо та мова солодша для неї од медової речі найрозумнішої людини. Лише після цього авторська інтенція спрямовується на побудову тексту за відповідною схемою оповідач-старий козак - твердження про диво - психологічна стійкість об'єкта - диво — натяк на негаразди суб' єкта, до початку якої слід додати елемент — „шана до України”.

Елементи побудованої схеми ініціації читача "твердження про диво" й "психологічна стійкість об'єкта" вербалізовано одночасно вживанням номінативних одиниць запорожець і характерник, які несуть культурно-історичну конотацію, що передбачає високий рівень довіри до такого джерела інформації, а також неабияку психологічну стійкість, досвід і фізичну силу об'єкта: Дід мій був запорожеиь. Де йому на віку не довелось бувати, чого не бачити! Удався він високий, здоровий та ще в додаток був і великий характерник: знався з відьмами, з чортами, нічого на світі не боявсь - правдивий був запорожеиь!

Наступний елемент схеми ініціації "диво", як і в тексті оповідання Втоплениия, не несе негативної конотації й навіть після з'ясування нетиповості поведінки суб'єктів страху викликає зацікавлення, а не страх: Став приглядуваться - аж недалечко стоїть високий козак у кармазиновім жупані, в чорних оксамитових шттанях і жовтих чоботях... такий з нього чуприндир, що кращого не знайти й у коші! Стоїть проти місяия і руками розмахує, неначе кого до себе манить; $i$ як махне рукою, то аж дерево до його нахиляється $і$ мого діда неначе хто у потилицю штовха. „Що воно за біс, - подумав дід, - чи не характерник...". Хотів вже був до його обізваться, коли чує - щось гепнуло за деревами та так іскрами кругом і обсипало. Дивиться - із-за кущів вийшла височенька дівчина, що кращої і у сні не побачиш. Несміливо підійшла вона до козака, згорнувши на грудях руки. - Чого ти мене звав? - спитала дівчина таким голоском, що у мого діда аж серие тьохнуло. Суб'єкти страху, як уже було з'ясовано, в українських текстах жахів того періоду можуть номінуватися нейтральними лексемами типу панночка, козак, дівчина, й лише вербалізація їхніх нехарактерних рис зовнішності або поведінки (Як имокнув, так по усій пущі луна і пішла; дерева заколихались, гілля до гіллі прихилилось, затуркали горлииі, i мого діда нахилило до землі; Повернулась з плечей - ще краща; тільки роздивився дід - аж хвостик! Так собі, невеличкий, та, матері його біс, —хвостик! Виходить, що дівчина відьма. Глянув на козака - аж і в того хвіст такий довгий, як у хорта, так їм виграє, як кіт перед мишею) дозволяє читачеві спрямувати свої очікування до сприймання тексту як жахливого. 
Але в цьому тексті все ж таки етап ініціації читача спрямовує його на розуміння більш гуманістичної інтенції автора - виховання в читача емпатії через переборення страху, що вербалізовано клятвою в коханні в останньому елементі схеми "натяк на негаразди суб'єкта страху": Питаєш, чого, - промовив козак, - хіба не знаєш, як я тебе кохаю?.. Без тебе мені й пекло не миле!..

Оповідання Київські відьми Ореста Соміва ${ }^{14}$, хоча і містить семіотичний маркер відьма в назві й може бути зараховане до тих оповідань, у яких текстотворча стадія ініціації читача починається з назви, але їі тлумачення для спрямування очікування читача на етапі ініціації відбувається за іншою схемою: жінка (відьма) - чоловік (молодий козак - повернувся на батьківщчину - не з порожніми руками - палали щзками дівчата й молодиці). Тож атмосфера жаху тексту буде відповідати одному з відомих культурних страхів - страху перед жінкою, яку в християнській традиції уявляли спокусницею, відьмою, яка підкорює силу й войовничий дух чоловіків. Очікування читача, вихованого на пресупозиції християнства, скеровані на створення атмосфери жаху навколо молодого чоловіка, якого повинна занапастити жінка.

Текст оповідання Страхи Івана Гавришкевича ${ }^{15}$ також побудований на основі культурного страху перед жінкою, але первинна ініціація на рівні назви оповідання спрямовує очікування читача в найзагальнішому напрямку, що стає можливим шляхом уживання маркера страх - „стан хвилювання, тривоги, неспокою, викликаний чеканням чого-небудь неприємного, небажаного"16, однак деталізація ініціації читача у світ жаху сюжетно відсувається і, на нашу думку, ілюструє інтенцію автора, що відповідає моралізаторському духу українських творів жахів цього періоду. Первинною й основною інтенцією автора стає передача не естетики й культури жаху, а повчального задуму. Із перших слів читач дізнається про соціальний статус і повагу до тих, хто шанує християнські звичаї: Буде тому літ кільканадесять, справляв поминки стариий брат церкви Гаврило Пасічинський. Господар, кметь на весь Цапів, так горішній, як і долішній, наспрошував свояків, та кумів, та сватів, та урядників сільських повнісіньку хату. Ініціація ж саме у світ жахів відбувається після розпитування про небувальщину у вояка, який побачив світ: Bu самі виділи нехриста? Та я таке видів, щчо якби розказав, то вам розум перед страхом сховався би. $<\ldots>$ Поволі все стихло, хоч мак сій. Свіча поминанная яла ся догоряти - то липне синім по стіні поломнем, то згасне, то знову липне, а далі враз і стопилася й упала на лавку. Темнота груба окружила нас, лиш на стіні начертав криваво сходячий місяцьь образ вікония. Перш ніж читача поглине жахливий сюжет, вербалізація відповідної атмосфери довкілля формує його очікування, тож схема ініціації в цьому оповіданні відповідає такій моделі: шана християнства оповідач-вояка - питання - твердження про диво — опис довкілля. Така схема ініціації в процесі текстотворення жахів не попереджає про наступне розгортання сюжету й може бути початком будь-якого тексту жахів на основі одного з відомих культурних або біологічних страхів людини.

Моралізаторсько-повчальна інтенція українських текстів жахів впливає на побудову тексту й схему ініціації читача у світ жахів і в тому разі, коли тексти мають на меті висміювання й осуд такої соціальної проблеми, як пияцтво. У таких текстах (напр., оповідання Шапка Володимира Росковшенка ${ }^{17}$ ) першим

\footnotetext{
${ }^{14}$ О. С о м ів, Київські відьми, [в:] Огненний змій..., с. 53-63.

${ }^{15}$ I. Га в р иш ке в и ч, Страхи, [в:] Огненний змій..., с. 182-193.

${ }^{16}$ Словник сучасної української мови, [в:] Електронний ресурс: http://sum.in.ua (02.02.2013).

${ }_{17}^{17}$ В. Р о с ко в ш е н к о, Шапка, [в:] Огненний змій..., с. 182-193.
} 
елементом схеми стає опис народних гулянь типу вечорниць, ярмарку або релігійного свята: Тепер увесь цей люд квапився на ярмарок, куди вже з їхалися купці із сусіднього міста з різноманітними предметами сільської розкоші та розмістилися в полотняних наметах. Наступним елементом схеми стає номінація об'єкта страху; зазвичай це особа або особи чоловічої статі простого походження: Уэке, мабуть, була третя пополудні, коли Грицько і Тиміш зіткнулися лобами на ярмариі. Обоє були в літах $і$ малися за заможних та мудрих госnодарів. Об'єкт страху натрапляє на якусь побутову проблему або вступає в суперечку з іншими людьми, а це призводить до того, що розв'язання конфлікту відбувається в шинку: Гей, Тимку! Зажди купувати! - Що буде, те й буде, куме, а поки щзо зайдем з тобою та вип 'єм могорич. I насамкінець об' єкт страху опиняється в такому оточенні, де не може орієнтуватися, - він один і безпорадний. Це може бути вербалізовано, напр., пейзажним описом ночі й тиші: Чудова темна жовтнева ніч зодягла околицю своїм похмурим покривалом, в незглибимій висоті переморгувалися між собою яскраві зорі. Жоден різкий звук не будив заснулої природи, лише десь далеко бубонів свою одноманітну пісню гомінливий млин та журливо вила собака. Лише після цього чи то в уяві, чи то насправді 3 п'яничкою починають відбуватися страхітливі події. Тож схема ініціації читача в подібних текстах жахів має такий вигляд: гуляння — об'єкт страху — конфлікт — локус — ніч і самотність.

Моралізаторські інтенції українських текстів жахів того періоду яскраво втілені в оповіданні Григорія Квітки-Основ’яненка Мертвецький великдень ${ }^{18}$. Етап ініціації, як і в багатьох проаналізованих текстах, починається 3 назви, де автор вербалізує натяк на воскресіння мерців. Це створює атмосферу очікування чогось надзвичайно жахливого, адже Великдень у християнській традиції шанує воскресіння сина Божого і вважається світлим і радісним святом. Але, як і в інших моралізаторських текстах, деталізація етапу ініціації відставлена, і її першим елементом стає опис історії життя непутящого об'єкта страху: < .. > у Нечипора була уся батькова натура. Злодіяка такий, щзо ні з чим не розминеться: і ичгана обдурить, і стария обікраде; а пити? - так не переп'є його i Данилка, от щзо у того пана, щзо біля нас живе <...>. Недовго ж нагосподарював. У три годи рішивсь зовсім. Що була скотинка, позбував, а грошики попропивав; земельку позакладував, а грошики попропивав; а щзо було опріч того, те від недогляду попропадало само. П' $\epsilon$, та краде, та ловиться; б'ється та позивається. Номінація об'єкта страху (злодіяка) й вербалізація його дій концентрує увагу читача на моральному осуді героя й скеровує очікування в напрямку того, що життя такої людини, відповідно до принципів християнської моралі, скінчиться погано. Тож етап ініціації читача в цьому тексті репрезентує таку схему: опис жаху — моральний осуд об'єкта.

Повчальна інтенція й моральний осуд об'єкта впливає на текстотворення оповідань, де християнська мораль протиставлена язичницьким віруванням (Чудний цввіт Федіра Заревича ${ }^{19}$, Як нажито, так $i$ прожито Хоми Купрієн$\mathrm{ка}^{20}$ ), завдяки слідуванню яким герой стає об'єктом страхів і неодмінно зазнає страждань і зіштовхується із жахами. Як видно із назв оповідань, вони можуть і не входити до складу етапу ініціації — він складається 3 вербалізації об 'єкта cmpaxy - зазвичай людини, яка чимось невдоволена у своєму житті й не хоче

${ }^{18}$ Г. К в і тка-О сн ов' ян ен ко, Мертвецький великдень, [в:] Електронний ресурс: http:// argo-unf.at.ua.

${ }^{19}$ Ф. З З р е в и ч, Чудний ивіт, [в:] Огненний змій..., с. 253-257.

${ }^{20} \mathrm{X}$. Куп ріє н ко, Як нажсито, так і прожсито, [в:] Огненний змій..., с. 182-193. 
працювати або відчаїлася, й порадника, який підказує їй, як подолати проблеми в “аморальний” спосіб, та, відповідно, самої поради, що закінчується застереженням про очікування небезпеки. Також у тексті може бути вербалізоване посилання на успішне слідування подібній пораді іншою людиною, що докорінно змінило іiі життя на краще. Такий маркер допомагає, з одного боку, підсилити достовірність поради, а з іншого, - зацікавити й скерувати очікування читача на фантастичні й страшні події. Напр., у Чудному извіті повідомляється: Бувало, чи не щзодень розказує небіжка тета за якийсь чудний ц̧віт, а ніколи не хотіла доповісти. А ми [дівчата] ичікаві були страх знати, щзо то за чудний цьвіт, та нудьгали тету й просили. <... Р Горпина, - гарна то була дівка, каже нам, щзо була у ворожки Стасихи, та радила їй она, аби пішли урвати чудного цзвіту, то з ним, щзо й схоче, потрафить зробити. <..> Оно, те зілля, раз щзо дуже далеко шукати й уночі по него йти, а друге - хто його не принесе, той $і$ долю свою віднесе, $i$ більше з нею не побачиться. Затям же, дівонько: я ти вповім, але сли не підеш і не принесеш, то тілько й мала ти долі, небого! Або наприклад, у творі Як нажито, так і прожито читаємо: < ...> се було на Івана Купала (...) Oт тепер би, - сказав один [парубок], - йому сп'яну не диво піти $i$ в ліс за папороттю. Кажуть, щзо як піти опівночі в ліс і вирвати сю траву, то щзо забажаєш, те й буде. Грошей можна стільки мати, щзо за все життя їх не витратиш. От би тобі, Іване, таке щзастя! Пив би вже безпробудно! Як вирвеш ї̈, то треба мерщій тікать з лісу і не озираться. I хто б тебе не кликав, $i$ щзо тобі не буде представлятись, а ти все біжи й не озирайся, а то все пропаде i ти сам пропадеш. А коли винесеш папороть, то вже гроші в тебе ніколи не переведуться. Тож схема ініціації в текстах такого типу може бути репрезентована так: об'єкт страху — порадник - порада — (третя особа) - застереження.

Отже, аналіз українських текстів літератури жахів XIX сторіччя дає змогу виокремити низку схем побудови початкового етапу їхнього текстотворення, що пропонуємо назвати ініціацією читача. До складу цих схем входять компоненти, вербалізація яких, по-перше, маркує текст як жахливий, по-друге, враховує національну специфіку текстів цього жанру i, по-третє, спрямовує читацьке очікування щодо текстосприйняття. Таким чином, можна засвідчити наявність зумовленості читацького текстосприйняття й відповідної скерованості його очікування вже на етапі ініціації, що свідчить про об’єктивність виокремлення цієї частини смислоутворювальної схеми текстів жахів, а також про перспективи аналізу текстотворення жахів з огляду на схеми їхньої організації, що можуть відображати не лише національну специфіку, а й загальнолюдські цінності, психологічне підгрунтя страху та різновиди його сприйняття й вираження. 